\title{
UPAYA PREVENTIF NOTARIS DALAM MEMBUAT AKTA AGAR TERHINDAR TINDAK PIDANA PENCUCIAN UANG
}

\author{
Agung Iriantoro \\ Magister Kenotariatan Universitas Pancasila
}

\begin{abstract}
ABSTRAK
Notaris sebagai pejabat umum dalam menjalankan jabatannya harus mengenali dan memahami norma-norma dan unsur dalam delik pidana yang diatur dalam Kitab Undang-Undang Hukum Pidana (KUHP), mengenali dan memahami kewenangan atributif yang terdapat dalam Undang-Undang Jabatan Notaris (UUJN). Notaris juga dapat terlibat Tindak Pidana Pencucuian Uang (TPPU). Untuk dapat terhindar dari TPPU notaris harus ada upaya preventif dengan memahami norma-norma, memenuhi kewajiban-kewajiban dan menjauhilarangan yang dimuat dalamUndang-Undang Tindak Pidana Pencucian Uang (UU TPPU), termasuk penambahan klausul yang memberi jaminan dananya tersebut tidak berasal dari tindak pidana kejahatan atau perbuatan hukum lain yang melawan hukum.
\end{abstract}

\begin{abstract}
Notary as a public official in carrying out his position must recognize and understand the norms and elements in criminal offenses regulated in the Criminal Code (KUHP), recognize and understand the attributive authority contained in the Notary Position Act (UUJN). Notaries can also be involved in Money Criminalization Crime (TPPU). To be able to avoid the notary TPPU, there must be a preventive effort by understanding the norms, fulfilling obligations and avoiding the prohibitions contained in the Money Laundering Criminal Act (TPPU Act), including the addition of clauses that guarantee that the funds do not come from acts criminal offenses or other legal actions that are against the law.
\end{abstract}

\section{A. PENDAHULUAN}

Notaris merupakan satu-satunya pejabat umum yang berhak membuat akta otentik sebagai alat pembuktian yang sempurna. ${ }^{1}$ Setidaknya

Pengurus Pusat Ikatan Notaris Indonesia, Editor Anke Dwi Saputra, Jati Diri Notaris Indonesia Dulu, Sekarang Dan Dimasa Yang Akan Datang, Jakarta: Gramedia, 2008, hlm. 34 
mempunyai dua makna penting. Pertama, Notaris memiliki kewenangan sebagaimana dimaksud dalam Pasal 1 angka 1 Undang-Undang Nomor 2 Tahun 2014 tentang Jabatan Notaris (UUJN), yaitu Notaris sebagai pejabat umum yang berwenang untuk membuat akta autentik dan memiliki kewenangan lainnya sebagaimana dimaksud dalam Undang-Undang ini atau berdasarkan Undang-Undang lainnya. Kedua, kewenangan yang dimiliki Notaris tersebut, sepanjang tidak ada peraturan yang memberi wewenang serupa kepada pejabat lain. ${ }^{2}$ Dengan demikian Notaris sebagai jabatan representasi dari Pemerintah untuk melayani masyarakat. Namun kewenangan Notaris dalam pelaksanaanya ketika menjalankan jabatannya mempunyai potensi untuk melanggar hukum yang berimplikasi pada sanksi pidana.

Notaris dapat dinyatakan melakukan tindak pidana apabila dalam praktik pembuatan Akta, Notaris melakukan:

1. pemalsuan dokumen atau surat (Pasal 263 dan 264 KUHP);

2. menyuruh memasukkan keterangan palsu kedalam akta otentik (Pasal 266 KUHP);

3. membantu melakukan suatu perbuatan \{Pasal 56 ayat (1), (2). jo Pasal 263 ayat (1), (2), Pasal 264, Pasal 266 KUHP\};

4. penggelapan (Pasal 372, Pasal $374 \mathrm{KUHP}$ );

5. keterangan palsu (Pasal 242 KUHP);

6. memberikan keterangan palsu dibawah sumpah (Pasal $242 \mathrm{KUHP}$ );

7. menerima hadiah/janjikarena kekuasaan/kewenangan berhubungan dengan jabatannya (Pasal 418 KUHP);

8. pejabat menerima hadiah atau janji, untuk menggerakkan supaya melakukan atau tidak melakukan sesuatu dalam jabatannya (Pasal 419 KUHP);

9. Pasal 55 KUHP: turut serta melakukan tindak pidana; dan

10. Pasal 231 KUHP: membantu pelaku dalam melakukan kejahatan

Selain itu, Notaris dapat terlibat dalam tindak pidana jika Notaris tidak melaporkan transaksi keuangan mencurigakan dan berbuah kejahatan, maka Notaris menghadapi ancaman pidana sebagaimana yang diatur dalam Pasal 5 Undang-Undang Nomor 8 Tahun 2010 tentang Pencegahan dan Pemberantasan Tindak Pidana Pencucian Uang(UU TPPU) yaitu tindak pidana pencucian uang pasif, Pasal 55 KUHP (turut serta) dan Pasal 56 KUHP

2 C.S.T Kansil, et. al., Pokok-Pokok Etika Profesi Hukum, Jakarta: Pradnya Paramita, 2003, hlm. 87. 
(ikut aktif membantu kejahatan).

Berdasarkan uraian di atas, dapat disimpulkan bahwa jabatan Notaris mempunyai potensi besar terlibat dalam tindak pidana ketika sedang menjalankan tugas dan wewenangnya. Sebab itu, Notaris perlu untuk melakukan tindakan preventif sebagai upaya mencegah Notaris terlibat dalam tindak pidana. Masalahnya bagaimana upaya tindakan preventif yang dapat dilakukan oleh Notaris sebagai pembuat Akta agar tidak terlibat dalam tindak pidana ketika membuat Akta?

\section{B. ANALISIS DAN PEMBAHASAN}

1. Upaya Preventif Notaris Terkait Dengan Tindak Pidana yang Diatur Dalam Kitab Undang-Undang Hukum Pidana

\section{a. Mengenali dan Memahami Norma dan Unsur Delik Pidana yang terdapat dalam KUHP}

Turut serta melakukan tindak pidana dalam Pasal 55 ayat (1) KUHP yang menyebutkan:

Dipidana sebagai pelaku tindak pidana:

a. yang melakukan, yang menyuruh melakukan, dan yang turut serta melakukan perbuatan; dan

b. yang dengan memberi atau menjanjikan sesuatu, dengan menyalahgunakan kekuasaan atau martabat, dengan kekerasan, ancaman atau penyesatan, atau dengan memberi kesempatan, sarana atau keterangan, sengaja menganjurkan orang lain supaya melakukan perbuatan.

Merujuk pada Pasal 55 KUHP di atas, meununjukan terdapat empat golongan yang dapat dipidana:

1) pelaku atau pleger;

2) menyuruh melakukan atau doenpleger;

3) turut serta atau medepleger;

4) penganjur atau uitlokker.

Sebagai contoh penerapan Pasal 55 ayat (1) KUHP dihubungkan dengan Pasal 266 ayat (1) KUHP, unsur "turut serta atau medepleger", maka kontruksi hukumnya seorang Notaris dinyatakan sebagai "orang yang melakukan menyuruh menempatkan keterangan palsu ke dalam suatu akta otentik ...", adalah suatu hal yang tidak mungkin dilakukan oleh seorang Notaris, 
karena: ${ }^{3}$

1) akta yang dibuat berupa akta partie/akta pihak, yaitu akta yang dibuat oleh notaris berdasarkan atas permintaan para pihak untuk mencatat atau menuliskan segala sesuatu hal yang dibicarakan oleh pihak berkaitan dengan tindakan hukum;

2) "orang yang menyuruh melakukan" menurut Pasal 55 ayat (1) KUHP adalah yang melakukan semua unsur tindak pidana, maknanya:

a) jika dikaitkan dengan kedudukan seorang notaris yang membuat akte partie, adalah suatu hal yang berlebihan dan tidak mungkin bisa dilakukan, sebab tidak mungkin notaris akan menyuruh para pihak untuk menempatkan keterangan palsu di dalam akta otentik yang dibuat oleh notaris tersebut, melainkan hal itu merupakan keinginan para pihak yang menyuruh notaris membuat akta;

b) jika Notaris, dinyatakan sebagai "orang yang menyuruh melakukan menyuruh menempatkan keterangan palsu ke dalam suatu akta otentik ...", tidak mungkin dilakukan Notaris, karena ke dua belah pihak yang datang kepada Notaris untuk membuatkan akta tersebut, dan hal tersebut merupakan kesepakatan ke dua belah pihak untuk dituangkan di dalam akta, serta suatu hal yang aneh juga notaris sebagai pejabat yang berwenang merupakan orang yang mempunyai kehendak melakukan tindak pidana menyuruh ke dua belah pihak untuk menempatkan keterangan palsu pada akta yang mereka kehendaki bersama, karena keterangan yang ada di dalam akta merupakan kesepakatan ke dua belah pihak.

Seseorang yang memberikan keterangan di atas sumpah atau yang biasa disebut delik sumpah palsu atau keterangan palsu diatur dalam Pasal 242 ayat (1) dan ayat (2) KUHP:

(1) Barangsiapa dalam keadaan di mana undang-undang menentukan supaya memberi keterangan di atas sumpah atau mengadakan akibat hukum kepada keterangan yang demikian, dengan sengaja memberi keterangan palsu di atas sumpah, baik dengan lisan ataupun tulisan, secara pribadi maupun oleh kuasanya yang khusus ditunjuk untuk itu, diancam dengan pidana penjara paling lama tujuh tahun.

3 Hilda Sophia Wiradiredja, Pertanggungjawaban Pidana Notaris Dalam Pembuatan Akta Yang Didasarkan Pada Keterangan Palsu Dihubungkan Dengan Undang-Undang Nomor 30 Tahun 2004 Tentang Jabatan Notaris Jo Undang-Undang Nomor 2 Tahun 2014 dan KUHP. Jurnal Wawasan Hukum, Vol. 32, No. 1, Februari 2015. 
(2) Jika keterangan palsu di atas sumpah diberikan dalam perkara pidana dan merugikan terdakwa atau tersangka yang bersalah diancam dengan pidana penjara paling lama tujuh tahun.

Menurut R. Soenarto Soerodibroto, menyebutkan syarat dari tindak pidana tersebut, meliputi: 4

1) suatu ketentuan undang-undang yang menghendaki suatu keterangan di bawah sumpah atau yang mempunyai akibat-akibat hukum; dan

2) pemberian keterangan palsu dan kesengajaannya ditujukan kepada kepalsuannya itu.

Perbuatan Notaris melakukan tindak pidana pemalsuan atau memalsukan surat, dalam UU Jabatan Notaris tidak diatur secara khusus tentang ketentuan pidana tersebut. Tetapi diatur dalam Pasal 263 KUHP: ${ }^{5}$

(1) Barangsiapa membuat secara palsu atau memalsukan suatu surat yang dapat menimbulkan suatu hak, suatu perikatan atau suatu pembebasan utang, ataupun yang dimaksud untuk membuktikan sesuatu kenyataan, dengan maksud untuk untuk menggunakannya sebagai surat yang asli dan tidak dipalsukan atau untuk membuat orang lain menggunakan surat tersebut, maka jika dari penggunaannya dapat menimbulkan suatu kerugian, karena bersalah melakukan pemalsuan surat, dipidana dengan pidana penjara selama-lamanya enam tahun.

(2) Dipidana dengan pidana yang sama, barang siapa dengan sengaja menggunakan surat tersebut sebagai surat yang asli dan tidak dipalsukan, jika dari penggunaannya dapat menimbulkan sesuatu kerugian.

Unsur-unsur tindak pidana yang diatur dalam Pasal 263 ayat (1) KUHP meliputi:

1) unsur subjektif : dengan maksud untuk menggunakannya sebagai surat yang asli dan tidak dipalsukan atau untuk membuat orang lain menggunakan surat tersebut;

2) unsur objektif :

a) barangsiapa;

b) membuat secara palsu atau memalsukan;

4 R. Soenarto SoerodibrotoKUHP dan KUHAP Dilengkapi Yurisprudensi Mahkamah Agung dan Hoge Raad, RajaGrafindo Persada (Rajawali Pers), Cet/ Edisi : Edisi 5 Cet 15. Tahun Terbit, 2011.

5 P.A.F. Lamintang dan Theo Lamintang, Delik-Delik Khusus (Kejahatan Membahayakan Kepercayaan Umum Terhadap Surat, Alat Pembayaran, Alat Bukti, dan Peradilan), Edisi Kedua, Sinar Grafika, Jakarta, 2009, hlm 6-8. 
Agung Iriantoro - UPAYA PREVENTIF NOTARIS DALAM MEMBUAT AKTA ...
c) suatu surat yang dapat menimbulkan suatu hak, suatu perikatan aau suatu pembebasan utang atau;
d) suatu surat yang dimaksud untuk membuktikan suatu kenyataan; dan
e) penggunaannya dapat menimbulkan suatu kerugian.

Di dalam ketentuan pidana yang diatur dalam Pasal 263 ayat (1) KUHP tersebut, pembentuk undang-undang ternyata tidak mensyaratkan keharusan adanya unsur kesengajaan atau unsur opzet pada diri pelaku, sehingga timbul pertanyaan apakah tindak pidana yang dimaksudkan didalam ketentuan pidana yang diatur dalam Pasal 263 ayat (1) KUHP harus dilakukan dengan sengaja atau tidak?

Dengan demikian, untuk dapat menyatakan seseorang yang didakwa melakukan tindak pidana pemalsuan surat sebagaimana yang dimaksud dalam Pasal 263 ayat (1) KUHP, harus memenuhi unsur pidana dari tindak pidana pemalsuan, meliputi: 6

1) pada waktu memalsukan surat itu harus dengan maksud akan menggunakan atau menyuruh orang lain menggunakan surat itu seolaholah asli dan tidak dipalsukan;

2) penggunaannya harus dapat mendatangkan kerugian. Kata "dapat" maksudnya tidak perlu kerugian itu betul-betul ada, baru kemungkinan saja akan adanya kerugian itu sudah cukup;

3) yang dihukum menurut pasal ini tidak saja yang memalsukan, tetapi juga sengaja menggunakan surat palsu. Sengaja maksudnya bahwa orang yang menggunakan itu harus mengetahui benar-benar bahwa surat yang digunakan itu palsu. Jika tidak tahu akan hal itu, tidak dihukum. Sudah dianggap "mempergunakan" misalnya menyerahkan surat itu kepada orang lain yang harus mempergunakan lebih lanjut atau menyerahkan surat itu di tempat dimana surat tersebut harus dibutuhkan;

4) dalam hal menggunakan surat palsu harus pula dibuktikan bahwa orang itu bertindak seolah-olah surat itu asli dan tidak dipalsukan, demikian pula perbuatan itu harus dapat mendatangkan kerugian.

Jika kehendak pengetahuan dan maksud terdakwa tersebut atau salah satu dari kehendak, pengetahuan dan maksud terdakwa tersebut ternyata tidak dapat dibuktikan, maka tidak ada alasan untuk hakim atau penuntut

6 R. Soesilo, Kitab Undang-undang Hukum Pidana (KUHP) Serta Komentar-Komentarnya Lengkap Pasal Demi Pasal,Bogor: Politea, 1976, hlm 196 
umum menyatakan terdakwa terbukti telah dengan sengaja melakukan tindak pidana yang didakwakan kepadanya dan hakim harus memberikan putusan ontslag van rechtsvervolging atau bebas dari tuntutan hukum ataupun lepas dari tuntutan hukum bagi terdakwa.

Bentuk pemalsuan surat, dilakukan dengan cara:?

1) membuat surat palsu: membuat isinya bukan semestinya (tidak benar);

2) memalsu surat: mengubah surat sedemikian rupa sehingga isinya menjadi lain dari isi yang asli. Caranya bermacam-macam, tidak senantiasa surat itu diganti dengan yang lain, dapat pula dengan cara mengurangkan, menambah atau merubah sesuatu dari surat itu;

3) memalsu tanda tangan juga termasuk pengertian memalsu surat; dan/ atau

4) menempelan foto orang lain dari pemegang yang berhak (misalnya foto dalam ijazah sekolah).

Ketentuan dalam Pasal 264 KUHP, berbunyi:

(1) Orang yang bersalah melakukan pemalsuan surat dipidana dengan pidana penjara selama-lamanya delapan tahun, jika perbuatan tersebut dilakukan terhadap:

a. akta-akta otentik;

b. surat-surat utang atau setifikat-sertifikat utang dari sesuatu negara atau bagian dari negara tersebut atau dari sesuatu lembaga umum;

c. saham-saham atau surat-surat utang atau sertifikat-sertifikat saham atau utang dari sesuatu perkumpulan, yayasan, perseroan atau maskapai;

d. talon-talon, bukti-bukti dividen atau bunga dari salah satu surat seperti yang dimaksudkan dalam dua nomor yang terdahulu atau bukti-bukti yang dikeluarkan sebagai pengganti surat-surat tesebut;

e. surat-surat kredit atau surat-surat dagang yang diperuntukan guna diedarkan.

(2) Dipidana dengan pidana yang sama, barangsiapa dengan sengaja menggunakan salah satu pemalsuan surat palsu atau yang dipalsukan seperti yang dimaksud dalam ayat pertama seolah-olah surat tersebut merupakan sepucuk surat yang asli dan tidak dipalsukan, jika penggunaannya dapat menimbulkan suatu kerugian.

7 Ibid, hlm. 195 
Tindak pidana yang diatur dalam Pasal 264 KUHP tersebut, merupakan lex specialis dari ketentuan pidana yang diatur dalam Pasal 263 KUHP. Disamping itu, tindak pidana pemalsuan surat sebagaimana yang dimaksud dalam Pasal 264 ayat (1) KUHP merupakan tindak pidana pemalsuan surat dengan kualifikasi atau suatu gequalificeerde valsheid in geschriften. Pengertian Gekwalificeerde delicten yaitu delik yang mempunyai bentuk pokok yang disertai unsur yang memberatkan. ${ }^{8}$

Hakim harus dapat membuktikan:

1) adanya kehendak para pelaku untuk menggunakan salah satu surat palsu atau yang dipalsukan seperti yang dimaksud dalam Pasal 264 ayat (1) KUHP seolah-olah surat tersebut merupakan surat yang asli dan tidak dipalsukan;

2) adanya pengetahuan pada pelaku bahwa surat yang digunakan merupakan salah satu surat seperti yang dimaksud dalam Pasal 264 ayat (1) KUHP yang dipalsukan atau yang dibuat secara palsu.

Frasa "pemalsuan surat" dalam rumusan Pasal 264 ayat (1) KUHP mempunyai makna yang sama dengan frasa "pemalsuan surat" dalam rumusan Pasal 263 ayat (1) KUHP, meliputi perbuatan membuat secara palsu atau memalsukan.

Rumusan Pasal 264 ayat (2) KUHP melarang orang menggunakan akta otentik dan lain-lain yang dipalsukan, segera orang akan dapat mengetahui bahwa unsur subyektif dengan sengaja oleh pembentuk undang-undang telah ditempatkan di depan unsur menggunakan salah satu surat palsu atau yang dipalsukan seperti yang dimaksud dalam ayat pertama seolah-olah merupakan surat yang asli dan tidak dipalsukan, yang berarti bahwa hakim harus membuktikan mengenai kesengajaan pelaku untuk menggunakan salah satu surat palsu atau yang dipalsukan yang seolah-olah surat tersebut merupakan surat yan asli atau tidak dipalsukan.

Frasa "dapat menimbulkan suatu kerugian" sebagaimana yang tercantum dalam Pasal 264 ayat (2) KUHP, tidak perlu wajib benar-benar muncul sebab yang dipersyaratkan hanya kemungkinan potensi munculnya kerugian.

Ketentuan dalam Pasal 266 KUHP, berbunyi:

(1) Barang siapa menyuruh mencantumkan suatu keterangan palsu mengenai suatu hal didalam suatu akta otentik yang kebenarannya harus dinyatakan

8 Bambang Purnomo, Asas-asas Hukum Pidana, Ghalia Indonesia, Jakarta, 1983. hlm. 102 
oleh akta tersebut dengan maksud untuk menggunakannya atau untuk menyuruh orang lain menggunakannya seolah-olah keterangannya itu sesuai dengan kebenaran, dipidana dengan pidana penjara selama-lamanya tujuh tahun jika penggunaannya dapat menimbulkan sesuatu kerugian.

(2) Dipidana dengan pidana yang sama, barangsiapa dengan sengaja menggunakan akta tesebut seolah-olah isinya sesuai dengan kebenaran, jika penggunaannya dapat menimbulkan sesuatu kerugian.

Unsur-unsur tindak pidana yang diatur dalam Pasal 266 ayat (1) KUHP, meliputi:

1) unsur subjektif: dengan maksud untuk menggunakannya atau untuk menyuruh orang lain menggunakannya seolah-olah keterangannya itu sesuai dengan kebenaran;

2) unsur-unsur objektif:

a) barang siapa;

b) menyuruh mencantumkan suatu keterangan palsu mengenai suatu hal, yang kebenarannya harus dinyatakan oleh akta tersebut;

c) di dalam suatu akta otentik;

d) jika penggunaannya dapat menimbulakan sesuatu kerugian.

Merujuk pada rumusan Pasal 266 ayat (1) KUHP, ternyata tidak mensyaratkan keharusan dilakukan secara sengaja atau tidak sengaja, sehingga perlu dipertanyakan apakah tindak pidana yang harus dilakukan dengan sengaja atau bukan. Dengan disyaratkannya suatu maksud lebih lanjut berupa maksud untuk menggunakannya atau untuk menyuruh orang lain menggunakan seolah-olah keterangannya sesuai dengan kebenaran di dalam rumusan Pasal 266 ayat (1) KUHP, maka sudah jelas tindak pidana yang dilakukan harus dengan sengaja (opzettelijk delict). Karena itu, penuntut umum maupun hakim harus dapat membuktikan adanya unsur kesengajaan terhadap seseorang yang telah melakukan tindak pidana sebagaimana yang dimaksud dalam Pasal 266 ayat (1) KUHP.

Pembuktian yang harus dibuktikan oleh penutut umum dan hakim sebagaimana yang telah disebutkan di atas, mengenai bukti:

1) adanya kehendak pada terdakwa untuk menyuruh mencantumkan suatu keterangan palsu mengenai sesuatu hal didalam suatu akta otentik yang kebenarannya harus dinyatakan oleh akta otentik tersebut;

2) adanya pengetahuan pada terdakwa, bahwa akta tersebut merupakan suatu akta otentik; dan 
3) adanya maksud pada terdakwa untuk menggunakannya atau untuk menyuruh orang lain menggunakannya seolah-olah keterangannya yang tercantum dalam akta tersebut sesuai dengan kebenaran.

Rumusan Pasal 266 KUHP tersebut, mengenai akta otentik yang didalamnya seseorang menyuruh memasukkan keterangan palsu kedalam akta otentik tentang hal yang kebenarannya harus dibuktikan oleh akta itu dengan tujuan untuk memakai atau menyuruh orang lain memakai akta itu seolah-olah keterangan itu benar.

Merujuk pada rumusan yang tercantum dalam Pasal 266 KUHP tersebut, Notaris ketika melaksanakan tugas dan kewajiban membuat akta, maka secara materiil tidak dapat dituduh sebagai pihak yang turut serta terhadap terjadinya tindak pidana. Kebenaran materiil atas suatu akta pada dasarnya merupakan tanggung jawab dari para pihak sedangkan kebenaran formil dari akta tersebut menjadi tanggung jawab notaris. Jika ingin mengimplementasikan Pasal 266 KUHP maka harus ada keterkaitan antara materi akta dengan notaris, sebab itu secara teoritis notaris dapat terlepas dari tuntutan pidana kecuali dapat dibuktikan sebaliknya.

Penggelapan diatur dalam Pasal 372 dan Pasal 374 KUHP. Ketentuan dalamPasal 372 KUHP, menyebutkan:

Barang siapa dengan sengaja dan melawan hukum memiliki barang sesuatu yang seluruhnya atau sebagian adalah kepunyaan orang lain, tetapi yang ada dalam kekuasaannya bukan karena kejahatan diancam karena penggelapan, dengan pidana penjara paling lama empat tahun atau pidana denda paling banyak sembilan ratus rupiah.

Penggelapan dalam Pasal 372 KUHP sebagaimana disebutkan di atas, perbuatan mengambil barang milik orang lain sebagian atau seluruhnya, ketika penguasaan atas barang sudah ada pada pelaku, tetapi penguasaan itu terjadi secara sah.

Sedangkan Pasal 374 KUHP menyebutkan:

Penggelapan yang dilakukan oleh orang yang penguasaannya terhadap barang disebabkan karena ada hubungan kerja atau karena pencarian atau karena mendapat upah untuk itu, diancam dengan pidana penjara paling lama lima tahun.

Menurut R. Soesilo, Pasal 374 KUHP ini merupakan penggelapan dengan 
pemberatan. 9 Misalnya seorang Notaris dalam menjalankan jabatannya telah menerima honorarium atas jasa hukum berdasarkan kewenangannya dari para pihak. Tetapi Notaris tidak menerbitkan akta yang di buatnya dalam waktu yang cukup lama, karena telah menggunakan honorarium itu untuk kepentingan pribadi atau kepentingan lain, sehingga para pihak yang menggunakan jasa hukumnya dirugikan. ${ }^{10}$

\section{b. Memahami dan MengenaliKetentuan KHUP yang Digunakan Pelapor Untuk Menjerat Notaris}

Ketentuan KHUP yang digunakan Pelapor untuk menjerat Notaris, meliputi: (a) pemalsuan dokumen atau surat (Pasal 263 dan 264 KUHP); (b) menyuruh memasukkan keterangan palsu ke dalam akta otentik (Pasal 266 KUHP); (c) membantu melakukan suatu perbuatan \{Pasal 56 ayat (1) dan ayat (2) jo. Pasal 263 ayat (1), ayat (2), Pasal 264 dan Pasal 266 KUHP\}; dan penggelapan (Pasal 372 dan Pasal 374 KUHP; (c) pencucian uang; dan (d) keterangan palsu (Pasal 242 KUHP).

\section{c. Mengenali dan Memahami Kewenangan Notaris}

Kewenangan atributif (kewenangan yang diberikan UUJN) kepada Notaris dalam menjalankan tugas dan jabatannya, diatur dalam Pasal 15 UUJN yang menyebutkan bahwa:

(1) Notaris berwenang membuat akta otentik mengenai semua perbuatan, perjanjian, dan ketetapan yang diharuskan oleh peraturan perundangundangan dan/ atau yang dikehendaki oleh yang berkepentingan untuk dinyatakan dalam akta otentik, menjamin kepastian tanggal pembuatan akta, menyimpan akta, memberikan grosse, salinan dan kutipan akta, semuanya itu sepanjang pembuatan akta-akta itu tidak juga ditugaskan atau dikecualikan kepada pejabat lain atau orang lain yang ditetapkan oleh undang-undang.

(2) Notaris berwenang pula:

a. mengesahkan tanda tangan dan menetapkan kepastian tanggal surat dibawah tangan dengan mendaftar dalam buku khusus;

9 R. Soesilo, Kitab Undang-undang Hukum Pidana (KUHP) Serta Komentar-Komentarnya Lengkap Pasal Demi Pasal,Bogor: Politea, 1989.

$10 \mathrm{Ibid}, \mathrm{hlm} 72$. 
Agung Iriantoro - UPAYA PREVENTIF NOTARIS DALAM MEMBUAT AKTA ...

b. membukukan surat-surat dibawah tangan dengan mendaftar dalam buku khusus;

c. membuat kopi dari asli surat-surat dibawah tangan berupa salinan yang memuat uraian sebagaimana ditulis dan digambarkan dalam surat yang bersangkutan;

d. melakukan pengesahan kecocokan fotokopi dengan surat aslinya;

e. memberikan penyuluhan hukum sehubungan dengan pembuatan akta;

f. membuat akta yang berkaitan dengan pertanahan;atau

g. membuat akta risalah lelang

(3) Selain kewenangan sebagaimana dimaksud pada ayat (1) dan ayat (2), Notaris mempunyai kewenangan lain yang diatur dalam peraturan perundang-undangan.

\section{Upaya Preventif Notaris Terkait DenganUndang-Undang Nomor 8 Tahun 2010 tentang Pencegahan dan Pemberantasan Tindak Pidana Pencucian Uang}

Tindak pidana pencucian uang merupakan tindak pidana yang dilakukan oleh pelaku dengan berusaha menyembunyikan atau menyamarkan asal usul Harta Kekayaanyangmerupakan hasil daritindakpidana denganberbagaicara agar Harta Kekayaan hasil tindak pidananya sulituntuk ditelusurioleh penegak hukum. Oleh karenaitu, tindak pidana pencucian uang tidak hanya mengancam stabilitas dan integritas sistem keuangan serta sistem perekonomian, tetapi juga dapat membahayakan sendi-sendi kehidupan berbangsa dan bernegara. Dalam mendukung pencegahan dan pemberantasan tindak pidana pencucian uang, Pemerintah bersama Dewan Perwakilan Rakyat telah membentuk Undang-Undang Nomor 8 Tahun 2010 tentang Pencegahan dan Pemberantasan Tindak Pidana Pencucian Uang(UU TPPU). ${ }^{11}$

Ketentuan dalam Pasal 17 ayat (2)Undang-Undang Nomor 8 Tahun 2010 tentang Pencegahandan Pemberantasan Tindak Pidana Pencucian Uang mengamanahkan untuk membuat Peraturan Pemerintah tentang Pihak Pelapor dalam Pencegahan dan Pemberantasan Tindak Pidana Pencucian Uang, yang kemudian dituangkan dengan Peraturan Pemerintah Nomor 43 Tahun 2015 Tentang Pihak Pelapor Dalam Pencegahan dan Pemberantasan

11 Penjelasan Peraturan Pemerintah Nomor 43 Tahun 2015 TentangPihak Pelapor Dalam Pencegahan dan Pemberantasan TindakPidana Pencucian Uang. 
Tindak Pidana Pencucian Uang.

Substansi yang diatur dalam Peraturan Pemerintah Nomor 43 Tahun 2015 Tentang Pihak Pelapor Dalam Pencegahan dan Pemberantasan Tindak Pidana Pencucian Uang, meliputi: ${ }^{12}$

a. menambah jenis penyedia jasa keuangan yang terdiri atas perusahaan modalventura, perusahaan pembiayaaninfrastruktur, lembagakeuangan mikro, dan lembaga pembiayaan ekspor sebagaiPihak Pelapor; dan

b. menyatakan advokat, notaris, pejabat pembuat akta tanah, akuntan, akuntan publik, dan perencana keuangan sebagai Pihak Pelapor. Penambahan jenis penyedia jasa keuangan yang terdiri atas perusahaan modal ventura, perusahaan pembiayaan infrastruktur, lembaga keuangan mikro, dan lembaga pembiayaan ekspor sebagai Pihak Pelapor dilatarbelakangi oleh aktivitas bisnis atau usaha yang dilakukan oleh perusahaan atau lembaga tersebut rentan untuk dijadikan sarana dan sasaran tindak pidana pencucian uang.

Dalam konteks Notaris, berdasarkan hasil riset PPATK, Notaris merupakan salah satu profesi yang rentan dimanfaatkan pelaku tindak pidana pencucian uang untuk menyembunyikan atau menyamarkan asal usul harta kekayaan yangmerupakan hasil dari tindak pidana dengan cara berlindung dibalik ketentuan kerahasiaan hubungan profesi dengan Pengguna Jasa yangdiatur sesuai dengan ketentuan peraturan perundang-undangan. ${ }^{13}$

Hal ini sejalan dengan rekomendasi yang dikeluarkan oleh Financial Action Task Force (FATF) yang menyatakan bahwa terhadap profesi tertentu yang melakukan Transaksi Keuangan Mencurigakan untuk kepentingan atau untuk dan atas nama Pengguna Jasa wajib melaporkan Transaksi tersebut kepada Financial Intelligence Unit (dalam hal ini adalah PPATK). Kewajiban pelaporan oleh profesi tesebut telah diterapkan di banyak negara dan memiliki dampak positif terhadap pencegahan dan pemberantasan tindak pidana pencucian uang. ${ }^{14}$

Selain itu, pengaturan Pihak Pelapor dan pelaksanaan kewajiban pelaporan oleh notaris dimaksudkan untuk melindungi Pihak Pelapor tersebut dari tuntutan hukum, baik secara perdata maupun pidana. ${ }^{15}$

12 Penjelasan Peraturan Pemerintah Nomor 43 Tahun 2015 Tentang Pihak Pelapor Dalam Pencegahan dan Pemberantasan TindakPidana Pencucian Uang.

13 Penjelasan Peraturan Pemerintah Nomor 43 Tahun 2015 Tentang Pihak Pelapor Dalam Pencegahan dan Pemberantasan TindakPidana Pencucian Uang.

14 Ibid.

15 Ibid. 
Notaris dalam Pasal 3 huruf b Peraturan Pemerintah Nomor 43 Tahun 2015 TentangPihak Pelapor Dalam Pencegahan dan Pemberantasan Tindak Pidana Pencucian Uang dikategorikan kedalam salah satu profesi yang bertindak sebagai pihak pelapor. Ketentuan tersebut, diperkuat oleh Pasal 3 UU Nomor 8 Tahun 2010 tentang Pencegahan dan Pemberantasan Tindak Pidana Pencucian Uang (UU TPPU) disebutkan bahwa profesi Notaris disebut sebagai pihak pelapor.

Pengertian pelapor menurut Pasal 1 angka 3 UU TPPU adalah setiap orang yang menurut peraturan perundang-undangan yang mengatur mengenai pencegahan dan pemberantasan Tindak Pidana Pencucian Uang (TPPU) wajib menyampaikan laporan kepada PPATK.

Sebagai Pihak Pelapor, profesi Notaris diwajibkan untuk menyampaikan laporan Transaksi Keuangan Mencurigakan ke PPATKuntuk kepentingan atau untuk dan atas nama Pengguna Jasa (Pasal 8 Peraturan Pemerintah Nomor 43 Tahun 2015 TentangPihak Pelapor Dalam Pencegahan dan Pemberantasan TindakPidana Pencucian Uang). Jika Notaris tidak melaporkan transaksi keuangan mencurigakan dan berbuah kejahatan, maka Notaris menghadapi ancaman pidana sebagaimana yang diatur dalam Pasal 5 UU TPPU yaitu tindak pidana pencucian uang pasif dan turut serta (Pasal 55 KUHP)serta ikut aktif membantu kejahatan (Pasal 56 KUHP).

Tindakan preventif lain yang dapat dilakukakan Notaris agar terhindar dari tindak pidana dalam pembuatan Akta yaitu:

a. mengenali pengguna jasa seperti memberikan identitas dan informasi yang benar, sumber dana, dan tujuan transasksi pihak lain;

b. mengenali pengguna Jasa melalui cara; (1) identifikasi melalui pengumpulan informasi Pengguna Jasa yang dilakukan pada orang perseorangan, Korporasi dan perikatan lainnya; (2) verifikasi terhadap informasi dan dokumen yang dilaksanakan sebelum melakukan hubungan usaha dengan Pengguna Jasa; dan (3) meminta keterangan kepada pengguna jasa untuk mengetahui kebenaran formil dokumen dan apabila terdapat keraguan atas kebenaran formil dokumen, Notaris dapat meminta dokumen pendukung lainnya dari pihak yang berwenang. Dalam hal Notaris meragukan kebenaran informasi yang disampaikan pengguna jasa, maka wajib memutuskan hubungan dengan pengguna jasa sebagaimana yang diatur dalam Pasal 22 UU TPPU juncto Pasal 5 ayat (1) dan ayat (2) Peraturan Kepala PPATK No. 7 Tahun 2017 yang menyebutkan jika melakukan hubungan pemutusan, maka wajib 
melaporkannya kepada PPATK;

c. melakukan pemantauan kewajaran transaksi pengguna jasa. Dalam hal pencatatan transaksi dan sistem informasi seorang Notaris bertanggung jawab terhadap adanya pencatatan transaksi dan sistem informasi mengenai identifikasi, pemantauan, dan penyediaan laporan mengenai transaksi yang dilakukan oleh Pengguna Jasa. Pencatatan transaksi dan sistem informasi dapat dilakukan secara non elektronik maupun elektronik yang disesuaikan dengan kompleksitas dan karakteristik Notaris. Sistem informasi yang dimiliki memungkinkan Notarisuntuk menelusuri setiap transaksi apabila diperlukan, baik untuk keperluan internal dan/ atau kementerian yang menyelenggarakan urusan pemerintahan di bidang hukum, maupun dalam kaitannya dengan penegakan hukum;

d. memenuhi prinsip Good Corporate Governance berkaitan dengan transparasi informasi dan akuntabilitas sesuai dengan peraturan perundang-undangan;

e. memperhatikan international best practice

f. independensi bebas dari pengaruh atau tekanan dari pihak manapun; dan

g. keadilan dan kesetaraan untuk memenuhi hak-hak para pihak berdasarkan perjanjian dan peraturan perundang-undangan.

Selain itu, tindakan preventif yang dapat dilakukan Notaris untuk membantu pemerintah mencegah dan memberantas tindak pidana pencucian uang dapat:

a. menambahkan dalam salah satu klausulnya memberikan keterangan bahwa para pihak menjamin bahwa uang atau dananya tersebut tidak berasal dari perbuatan hukum lain; atau

b. membuat surat pernyataan bagi pengguna jasa bahwa uang yang akan atau telah disetor bukan merupakan uang hasil tindak pidana pencucian uang dan kejahatan lainnya.

\section{PENUTUP}

Berdasarkan analisis dan pembahasan di atas, dapat disimpulkan bahwa upaya tindakan preventif yang dapat dilakukan oleh Notaris sebagai pembuat Akta agar tidak terlibat dalam tindak pidana sebagaimana yang diatur dalam KUHP, meliputi: 
1. mengenali dan memahami norma dan unsur delik pidana yang terdapat dalam KUHP;

2. memahami dan mengenali ketentuan KUHP yang dapat digunakan pelapor untuk menjerat Notaris; dan

3. mengenali dan memahami kewenangan atributif Notaris yang diberikan UUJN;

Sedangkan upaya preventif Notaris terkait dengan UU TPPU meliputi:

1. kewajiban Notaris untuk melaporkan transaksi keuangan mencurigakan dan dapat berbuah kejahatan untuk menghindari ancaman pidana dalam Pasal 5 UU TPPU,Pasal 55 dan Pasal 56 KUHP;

2. mengenali pengguna jasa seperti memberikan identitas dan informasi yang benar, sumber dana, dan tujuan transaksi pihak lain;

3. melakukan verifikasi;

4. meminta keterangan kepada pengguna jasa untuk mengetahui kebenaran formil dokumen;

5. wajib memutuskan hubungan dengan pengguna jasa yang diatur dalam Pasal 22 UU TPPU juncto Pasal 5 ayat (1) dan ayat (2) Peraturan Kepala PPATK No. 7 Tahun 2017;

6. melakukan pemantauan kewajaran transaksi pengguna jasa;

7. memenuhi prinsip Good Corporate Governance;

8. memperhatikan international best practice;

9. menambahkan salah satu klausul yang memberikan jaminan dananya tersebut tidak berasal dari tindak pidana kejahatan atau perbuatan hukum lain yang melawan hukum; dan

10. membuat surat pernyataan bagi pengguna jasa bahwa uang yang akan atau telah disetor bukan merupakan uang hasil tindak pidana pencucian uang dan kejahatan lainnya.

\section{DAFTAR PUSTAKA}

Adjie, Habib, Memahami Hak Ingkar dan Kewajiban Notaris, (http://habibadjie. dosen.narotama.ac.id/files/2013/07/Memahami-Hak-Ingkar-dan Kewajiban-Ingkar-Notaris.pdf/

Kansil, C.S.T et. al., Pokok-Pokok Etika Profesi Hukum, Jakarta: Pradnya Paramita, 2003. 
Nurung, M, Notaris Tidak Tepat Dijadikan Saksi Hukum Perdata, Majalah Renvoi 12 Edisi Mei, 2006.

Purnomo, Bambang., Asas-asas Hukum Pidana,Ghalia Indonesia, Jakarta, 1983.

Wiradiredja,Hilda Sophia, Pertanggungjawaban Pidana Notaris Dalam Pembuatan Akta Yang Didasarkan Pada Keterangan Palsu Dihubungkan Dengan Undang-Undang Nomor 30 Tahun 2004 Tentang Jabatan Notaris Jo Undang-Undang Nomor 2 Tahun 2014 dan KUHP. Jurnal Wawasan Hukum, Vol. 32, No. 1, Februari 2015.

M. Nurung, Notaris Tidak Tepat Dijadikan Saksi Hukum Perdata, Majalah Renvoi 12 Edisi Mei, 2006.

P.A.F. Lamintang dan Theo Lamintang, Delik-Delik Khusus (Kejahatan Membahayakan Kepercayaan Umum Terhadap Surat, Alat Pembayaran, Alat Bukti, dan Peradilan), Edisi Kedua, Sinar Grafika, Jakarta, 2009.

Pengurus Pusat Ikatan Notaris Indonesia, Editor Anke Dwi Saputra, Jati Diri Notaris Indonesia Dulu, Sekarang Dan Dimasa Yang Akan Datang, Jakarta: Gramedia, 2008.

R. Soenarto SoerodibrotoKUHP dan KUHAP Dilengkapi Yurisprudensi Mahkamah Agung dan Hoge Raad, Raja Grafindo Persada (Rajawali Pers), Cet/ Edisi : Edisi 5 Cet 15. Tahun Terbit, 2011.

R. Soesilo. Kitab Undang-Undang Hukum Pidana (KUHP) Serta Komentar Komentarnya Lengkap Pasal Demi Pasal. Politeia, Jakarta, 1991. 